\title{
The effect of feeding diets with genetically modified cucumbers on the growth and health status of rats*
}

\section{Kosieradzka ${ }^{1}$, E. Sawosz ${ }^{1}$, B. Pastuszewska ${ }^{4}$, M. Szwacka ${ }^{2}$, S. Malepszy ${ }^{2}$, W. Bielecki ${ }^{3}$ and K. Czumińska ${ }^{3}$}

\author{
Warsaw Agricultural University, \\ 'Department of Animal Nutrition and Feed Science \\ Rakowiecka 26/30, 02-528 Warsaw, Poland \\ ${ }^{2}$ Department of Genetics, Breeding and Biotechnology of Plants \\ Nowoursynowska 166, 02-787 Warsaw, Poland \\ ${ }^{3}$ Faculty of Pathology \\ Grochowska 272, 03-849 Warsaw, Poland \\ ${ }^{4}$ The Kielanowski Institute of Animal Physiology and Nutrition, \\ Polish Academy of Sciences \\ 05-L10 Jablonna near Warsaw, Poland
}

\begin{abstract}
The composition of the fruits of non-transgenic or transgenic (GM) cucumbers with genes coding the synthesis of a sweet protein, thaumatin, were compared and effects of feeding the fruits in balanced diets to rats were determined. The transgenic cucumbers contained more protein $(20.3 \mathrm{vs}$ $17.9 \% \mathrm{DM}$ ) and less fibre (9.4 vs $11.4 \% \mathrm{DM}$ ) and also had lower $\mathrm{Na}, \mathrm{K}, \mathrm{Ca}$ and $\mathrm{Mg}$ contents and higher levels of $\mathrm{Fe}$ and $\mathrm{Cu}$ in ash than normal cucumbers. Feeding male rats of initial body weight $150 \mathrm{~g}$ for 5 weeks on isoprotein diets containing 0 or $15 \%$ lyophilized transgenic or non-transgenic cucumbers did not affect weight gain, apparent health status, or relative organ weights of animals. Protein digestibility was slightly but significantly lower ( $89.2 \mathrm{vs} 90.0 \%)$, that of crude fibre was higher (28.2 vs $15.0 \%)$ in diets containing transgenic than non-transgenic cucumbers, while digestibility of fat and $\mathrm{N}$-free extractives did not differ.
\end{abstract}

KEY WORDS: transgenic cucumbers, digestibility, internal organs, rats

\footnotetext{
* Supported by Warsaw Agricultural University, Grant No. 50407040011
} 


\section{INTRODUCTION}

One of the objectives of genetic modification of plants used for food and feed purposes is to increase their palatability by introducing genes coding the synthesis of sweet substances such as thaumatin. Thaumatin is a protein 2000 to 2500 times sweeter than saccharose (Szwacka et al., 1997) and, when introduced into vegetable and fruit plants, improves the taste of edible parts without increasing their calorific value (Faus, 2000).

The introduction of genes coding the synthesis of new proteins may change the proportions of other nutrients in the plant and induce allergenic or other unknown biological effects of protein. Nutritional studies either confirm (Pusztai, 1999) or do not confirm (Arabia, 1997; Faus, 1997; Brake and Vlachos, 1998; Kulma et al., 2000) the existence of any hazards, related to feeding transgenic plants. There is, however, general agreement that complex and extensive studies are necessary preceding introduction of GM plants as a food or feed component.

The objective of this experiment, which is part of a broader study on vegetal GMOs, was to examine the effects of feeding diets with a considerable proportion of transgenic cucumbcr on growth parameters, relative organ weights and nutrient digestibility in rats. The genetic modification consisted of introducing the gene coding thaumatin and the marker gene of resistance to kanamycin.

\section{MATERIAL AND METHODS}

The cucumbers were cultivated in the greenhouse of the Faculty of Genetics, Breeding and Biotechnology of Plants of Warsaw Agricultural University. The fruits were collected in a similar stage of growth (12-15 cm long), cut, and frozen to $-30^{\circ} \mathrm{C}$ and freeze-dried.

The chemical composition of the fruits, rat diets, and faeces was determined according to conventional methods (Skulmowski, 1974) using a Tecator apparatus. Mineral components in fruit lyophilizate were determined by atomic absorption spectrometry FAAS, the P content by atomic emission spectrometry ICP-AES 9.

The feeding experiment was conducted for 5 weeks on 3 groups of male rats from the outbred $\mathrm{IF}_{\mathrm{z}} \mathrm{Jaz}$ herd of a mean initial body weight $150 \mathrm{~g}$. Eight animals per treatment were fed on isoprotein casein diets containing 0 or $15.5 \%$ of nonGM or GM cucumber lyophilizate. The detailed composition of the diets is given in Table 1.

The rats were kept in individual cages, cnabling control of feed intake. During 7 days of the digestibility experiment, a total collection of faeces was performed. Faeces were frozen, dried at $60^{\circ} \mathrm{C}$ and after removal of hair, ground and analyzed. The body weight of the animals was checked once a week. After completion of the 
TABLE 1

Composition of the diets, $\%$

\begin{tabular}{lccc}
\hline \multirow{2}{*}{ Specification } & Control & \multicolumn{2}{c}{ Cucumber fruits } \\
\cline { 3 - 4 } & & non-transgenic & transgenic \\
\hline Cucumbers- lyophilizate & - & 15.0 & 15.0 \\
Casein & 14.5 & 11.2 & 10.9 \\
Cellulose & 4.0 & 2.3 & 2.60 \\
Oil & 4.0 & 4.0 & 4.0 \\
Vitamin mixture* & 3.0 & 3.0 & 3.0 \\
Mineral mixture* & 2.0 & 2.0 & 2.0 \\
DL-methionine & 0.12 & 0.09 & 0.09 \\
Maize starch & 72.38 & 62.41 & 62.41 \\
& & & \\
Crude protein & 10.79 & 10.86 & 10.62 \\
Crude fibre & 2.19 & 2.46 & 2.36 \\
Crude fat & 4.11 & 4.04 & 4.45 \\
\hline
\end{tabular}

* according to AOAC (1975)

** according to NRC (1976); in diets with the fruit lyophilizate, the following mixture was used: $\mathrm{CaHPO}_{4} \times 2 \mathrm{H}_{2} \mathrm{O}-139.44$; maize starch - 12.15; $\mathrm{K}_{2} \mathrm{SO}_{4}-10.20 ; \mathrm{NaCl}-14.50 ; \mathrm{CaCO}_{3}-3.15$; $\mathrm{Na}_{2} \mathrm{HPO}_{4}-3.21 ; \mathrm{MgO}-3.75$; microelements -2.70

experiment, the animals were killed by overdosing ketamine; the liver, kidney, caecum, pancreas, spleen, thymus, and heart were dissected and weighed.

Statistical analysis of the results was carried out using Statgraphics 4.1 for Windows. The significance of differences between the groups was determined by single-factor analysis of variance, using the Duncan test.

\section{RESULTS}

The fruit of transgenic cucumbers contained $2.3 \%$ more total protein, $2 \%$ less crude fibre, and somewhat less mineral compounds (crude ash) as compared with non-transgenic fruit (Table 2). Transgenicity caused a change in the composition of ash, decreasing the level of sodium, potassium, calcium, and magnesium while increasing the iron and copper contents.

The body weight gains of the rats fed isoprotein diets containing $15 \%$ cucumber lyophilizate and standard synthetic diet did not differ (Table 3 ).

Protein digestibility of both cucumber diets was slightly lower, whereas fibre and fat digestibilities were higher than of the control casein diet (Table 4). Protein digestibility was slightly but significantly lower while that of fibre, higher in the diet containing GM cucumbers; the digestibility of organic matter, fat and $\mathrm{N}$-free extractives did not differ. 
TABLE 2

Chemical composition of lyophilizate of non-GM and GM cucumber fruits, of Borszczagowski variety, \% in dry matter

\begin{tabular}{lcc}
\hline \multirow{2}{*}{ Specification } & \multicolumn{2}{c}{ Cucumber fruits } \\
\cline { 2 - 3 } & non-transgenic & transgenic \\
\hline Dry matter, \% & 87.00 & 87.10 \\
Crude ash, \% & 11.63 & 10.58 \\
Crude protein, \% & 17.98 & 20.26 \\
Crude fat, \% & 2.12 & 1.80 \\
Crude fibre, \% & 11.37 & 9.45 \\
Ca, \% & 0.68 & 0.51 \\
$\mathrm{Mg}, \%$ & 0.32 & 0.27 \\
$\mathrm{P}, \%$ & 0.75 & 0.73 \\
$\mathrm{~K}, \%$ & 4.99 & 3.97 \\
$\mathrm{Cu}, \mathrm{ppm}$ & 6.49 & 8.36 \\
$\mathrm{Zn}, \mathrm{ppm}$ & 45.10 & 45.20 \\
$\mathrm{Na}, \mathrm{ppm}$ & 830.00 & 665.00 \\
$\mathrm{Fe}, \mathrm{ppm}$ & 55.30 & 71.80 \\
\hline
\end{tabular}

TABLE 3

Weight gain of rats fed on control and experimental diets during 5 weeks, $g$

\begin{tabular}{lccccc}
\hline \multirow{2}{*}{ Specification } & \multirow{2}{*}{ Control } & \multicolumn{2}{c}{ Cucumber fruits } & \multirow{2}{*}{ SEM } & $\mathrm{P}$ \\
\cline { 3 - 4 } & & non-transgenic & transgenic & & \\
\hline Initial body weight, $\mathrm{g}$ & 150.0 & 148.8 & 149.6 & 2.213 & 0.921 \\
Final body weight, g & 281.1 & 278.0 & 275.7 & 2.083 & 0.211 \\
Body weight gain, $\mathrm{g}$ & 131.1 & 129.3 & 126.1 & 1.973 & 0.125 \\
\hline
\end{tabular}

TABLE 4

Digestibility coefficients of control and experimental diets, $\%$

\begin{tabular}{lccccc}
\hline \multirow{2}{*}{ Specification } & \multirow{2}{*}{ Control } & \multicolumn{2}{c}{ Cucumber fruits } & \multirow{2}{*}{ SEM } & P \\
\cline { 3 - 4 } & & non-transgenic & transgenic & & \\
\hline Organic matter & 95.4 & 95.2 & 95.1 & 0.136 & 0.299 \\
Crude protein & $94.2^{\mathrm{A}}$ & $90.0^{\mathrm{B}}$ & $89.2^{\mathrm{C}}$ & 0.162 & 0.000 \\
Crude fibre & $3.7^{\mathrm{C}}$ & $15.0^{\mathrm{B}}$ & $28.2^{\mathrm{A}}$ & 2.022 & 0.000 \\
Crude fat & $93.6^{\mathrm{B}}$ & $96.4^{\mathrm{A}}$ & $96.3^{\mathrm{A}}$ & 0.115 & 0.000 \\
N-free extractives & $98.5^{\mathrm{a}}$ & $98.0^{\mathrm{b}}$ & $98.4^{\mathrm{b}}$ & 0.157 & 0.053 \\
\hline
\end{tabular}

means in the columns, marked with the different letters ${ }^{A, B, C}$ differ significantly for $\mathrm{P}<0.01$; with letters ${ }^{\mathrm{a}, \mathrm{b}}$ for $\mathrm{P}<0.05$ 
The relative weights of the internal organs of control and experimental rats did not differ significantly.

\section{DISCUSSION}

Introduction of a sweet protein into the cucumber had two effects: it changed the composition of inorganic substances and the nutritional value of the fruit. Pure thaumatin easily reacts with certain groups of dyes; its numerous sulphur bonds may also show a predisposition to bind some metals with a variable valances (Higginbotham and Snodin, 1983). It may be supposed that by entering into contact with compounds containing $\mathrm{Fe}$ and $\mathrm{Cu}$, thaumatin stimulated their deposition in cucumbers. In pure form, thaumatin, a protein consisting of 207 amino acids and characterized by high solubility and good digestibility by humans, has a tendency to form complexes with anionic polysaccharides (Gibbs et al., 1996). It may be supposed that this may modify the digestibility of carbohydrates, especially of cucumber fibre.

The lack of any significant differences in the weight of internal organs points to a small effect of the experimental variables on their function; it seems, however, that excluding any negative influence of transgenicity on animal organisms requires determination of many other parameters and prolongation of feeding of experimental diets (Beever and Kemp, 2000).

The lack of a significant influence of modified cucumbers on the examined parameters is related to the nature of thaumatin. The substance, used as sweetener (E 957), is of natural origin, it occurs in katemfe fruit (the plant Thaumatococcus danieli), and is considered to be safe for health (Gibbs et al., 1996). A high level of thaumatin is allowed in human nutrition. However, it may be supposed that in new environment (cucumber fruit), thaumatin could create new compounds, not appearing until now, that modify the metabolic pathways in cucumber tissues, leading to qualitative and quantitative chemical changes. In studies on GM potatoes resistant to infestation (Pusztai et al., 1999), the transgenicity of the plant was connected with a rise in the concentration of a substance actively affecting the metabolism and physiology of animals; substances with an agglutinic effect are toxic in higher concentrations. The consequences of the effect of transgenic plants on a consumer's organism are directly dependent on the type of modification (and also its purpose), so the eventual risk may be partly foreseen at the stage of laboratory studies, chemical analyses of tissue composition and in vitro studies.

\section{CONCLUSIONS}

The introduction of the gene coding the synthesis of thaumatin changes the percentage content of basic nutritional components (it especially increases the to- 
tal protein content) and changes the mineral component content. It does not affect the growth and health of animals, but it does slightly affect nutrient digestibility.

The influence of feeding transgenic plants on animal organisms requires more thorough and longer studies.

\section{REFERENCES}

Araba M., 1997. Added-value grains; feed ingredients of the future. Multi-State Poultry Nutrition Conference. Indianapolis, Indiana (USA), pp. 1-28

Beever D.E., Kemp C.F., 2000. Safety issues associated with the DNA in animal feed derived from genetically modified crops. Nutr. Abstr. Rev., Ser. B 70, 175-182

Brake J., Vlachos D., 1998. Evaluation of transgenic event 176 "Bt" corn in broiler chickens. Poultry Sci. $77,648-653$

Faus I., 2000. Recent developments in the characterization and biotechnological production of sweet - tasting proteins. Appl. Microbiol. Biotechnol. 53, 2, 145-151

Gibbs B.F., Alli I., Mulligan C., 1996. Sweet and taste - modifying proteins: a revicw. Nutr. Res. 16, $1619-1630$

Higginbotham J.D., Snodin D.J., 1983. Safety evaluation of thaumatin. Food Chem. Toxicol. 21, $815-923$

Kulma A., Wilczyński G., Milcarz M., Prescha A., Szopa J., 2000. Modulation of carbohydrate metabolism in transgenic potato through genetic engineering and analysis of rabbits fed on wild type and transgenic potato tubers. Food Biotechnol. (in press)

Pusztai A., 1999. Effect of diets containing genetically modified potatoes expressing Galanthus nivalis lectin on rat small intestine. Lancet British Edition 354, 0187, 1353-1354

Skulmowski J., 1974. Methods of Feed Analyses (in Polish). PWRiL, Warszawa

Szwacka M., Morawski M., Malepszy S., 1997. Characterisation of cucumber plants obtained after transformation of cDNA gene of thaumatin II (in Polish). Zesz. Nauk AR Kraków 50, 517-520

\section{STRESZCZENIE}

\section{Wplyw żywienia dietami zawierającymi genetycznie modyfikowane ogórki na wzrost i stan zdrowia szczurów}

Porównano skład oraz wpływ podawania szczurom owoców ogórków nietransgenicznych i transgenicznych (GM), zawierajacych gen kodujący syntezę słodkiego białka taumatyny. Owoce transgenicznych ogórków GM zawierały więcej białka ( 20,3 vs $17,9 \%$ s.m.) i mniej wlókna (9,4 vs $11,4 \%$ s.m.), a także mniej $\mathrm{Na}, \mathrm{K}, \mathrm{Ca}$ i Mg, a więccj $\mathrm{Fc}$ i Cu w popicle, niż ogórki normalne. Żywienie szczurów (o począlkowej m.c. $150 \mathrm{~g}$ ) przez 5 tygodni pełnowartościowymi dietami zawierającymi 0 lub $15 \%$ liofilizowanych ogórków nietransgenicznych lub transgenicznych nie miało wpływu na wzrost i ogólny stan zdrowia zwierząt oraz masę narządów wewnętrznych. Strawność bialka była nieznacznie, ale istotnie niższa $(89,2$ vs $90,0 \%)$, a włókna surowcgo wyższa $(28,2$ vs $15,0 \%)$ w dietach zawierających ogórki transgeniczne niż nietransgeniczne, natomiast strawność tłuszczu i związków bezazotowych wyciagowych nie różniła się. 